\title{
OPTICAL DATING AND SEDIMENTARY RECORD FROM THE TERRACE DEPOSITIONAL PROFILE OF THE WARTA RIVER (CENTRAL POLAND)
}

\author{
DANUTA DZIEDUSZYŃSKA ${ }^{1}$, JOANNA PETERA-ZGANIACZ ${ }^{1}$, JULIUSZ TWARDY $^{\mathbf{1}}$, PIOTR KITTEL ${ }^{\mathbf{1}}$, \\ PIOTR MOSKA ${ }^{2}$ and GRZEGORZ ADAMIEC ${ }^{2}$ \\ ${ }^{I}$ Department of Geomorphology and Palaeogeography, Faculty of Geographical Sciences, University of Lodz, \\ ul. Narutowicza 88, 90-139 Lodz, Poland \\ ${ }^{2}$ Department of Radioisotopes, Institute of Physics-Centre for Science and Education, Silesian University of Technology, \\ ul. Krzywoustego 2, 44-100 Gliwice, Poland
}

Received 28 January 2014

Accepted 3 July 2014

\begin{abstract}
Results of OSL dating and sedimentary studies from the profile of the low alluvial terrace of the middle Warta River are presented. The samples were dated using the single-aliquot regenerative method. Dating was used to establish a timing of the Weichselian Late Glacial events in the river valley environment. Stable conditions on the floodplain are expressed by the deposition of organicrich series radiocarbon dated at 12 900-12 $600 \mathrm{cal}$ BP and 11 600-10 $770 \mathrm{cal}$ BP. Samples for OSL dating were collected from the mineral material deposited during the intensification of flood events during the Weichselian decline. The results obtained for the alluvia range from $12.78 \pm 0.62 \mathrm{ka} b 2 \mathrm{k}$ to $14.33 \pm 0.74 \mathrm{ka} \mathrm{b} 2 \mathrm{k}$. Sedimentological criteria allowed to distinguish between particular flood events. Overestimation of OSL ages is probably a result of rapidity of environmental changes in that time.
\end{abstract}

Keywords: palaeofloods, Younger Dryas, OSL, sedimentological studies.

\section{INTRODUCTION}

Timing of past events is one of the most crucial problems of palaeogeographical studies. The existence of sets of both radiocarbon and luminescence dates enables to reconstruct various environmental parameters, however the precision and accuracy depend among others on the investigated time period, type of dated material and depositional event. In defining the rate of processes with a relatively high resolution, basic distinction between particular sedimentary systems (e.g. fluvial, aeolian, glacial) may be insufficient and the recognition of a sedimentary subenvironment is required to understand the development of sedimentary processes. Satisfactory results of age

Corresponding author: D. Dzieduszyńska

e-mail: dadziedu@geo.uni.lodz.pl determination using radiometric dating methods are attained by a thorough recognition of the palaeogeography of the area from which depositional events are reported.

The present study focuses on the environmental processes which took place during the quite well recognized time of the Last Glacial Termination in the Warta River valley, Poland. The aim of the study was to establish the time relation between the formation of the organic series, whose age is determined by radiocarbon dating, and the accompanying deposits formed in a fluvial environment. Of particular importance is the determination of the formation time of the series overlying the organic material. This mineral sequence is the result of increased fluvial activity reflected in the flood intensification and overbank deposition. The age determination of the flood deposits may enable to locate this increased activity in the Young- 
er Dryas, in the time of efficient morphological processes induced by global dynamic climatic changes.

\section{SITE LOCATION}

The study area is located in Central Poland Lowland, in the middle section of the Warta River valley (Fig. 1a). The last ice cover was present there during the Wartanian Stage (Czubla et al., 2013). In the Eemian Interglacial the river bottom was situated about $15 \mathrm{~m}$ lower than today. During the whole Weichselian, a tendency to aggradation prevailed, mainly due to the subsidence (Widera, 2007). The thick sand series deposited in the wide valley were a source material to fluvial processes of the very end of the Weichselian and the Holocene.

The valley is incised there into a morainic plain and a fluvioglacial plain of Saalian age (Fig. 1b). The morphological elements of the valley are weakly expressed, mainly due to its wide extension, attaining there even up to $10 \mathrm{~km}$ in width. These include remains of erosional terraces of the Warsaw-Berlin ice marginal streamway and alluvial terraces: a higher one of the Middle Weichselian and a lower one, which stratigraphical position points to the late Younger Dryas.
The site under investigations, Koźmin Las, is located in Koźmin village (N 50 $04^{\prime} 51^{\prime \prime}$, E $\left.18^{\circ} 40^{\prime} 03^{\prime \prime}\right)$ at an altitude of $97.5 \mathrm{~m}$ above sea level, on the low terrace of the western side of the Warta River (Fig. 1b).

Studies at the Koźmin Las site were carried out in an open test pit. In the walls of this pit the sequence of deposits exposed to a depth of $2.6 \mathrm{~m}$ was registered. The depositional sequence consists of three lithological units: lower sandy unit, middle organic-rich unit and upper sandy and sandy-silty unit and makes up the general stratigraphy (Dzieduszyńska and Petera-Zganiacz, 2012). The same profile was reported from the coring sites distributed over the area of at least $20 \mathrm{~km}^{2}$.

\section{PREVIOUS STUDIES}

Properties of the deposits constituting the lower unit are known largely from earlier surveys performed along the walls of the Adamów lignite opencast mine. This unit is of a fluvial origin. Previous studies indicated its formation in a sand-bed braided river environment during the LGM and subsequent cold periods (Petera, 2002; Forysiak, 2005). For the purpose of the present work only topmost part of the lower fluvial unit was investigated, as

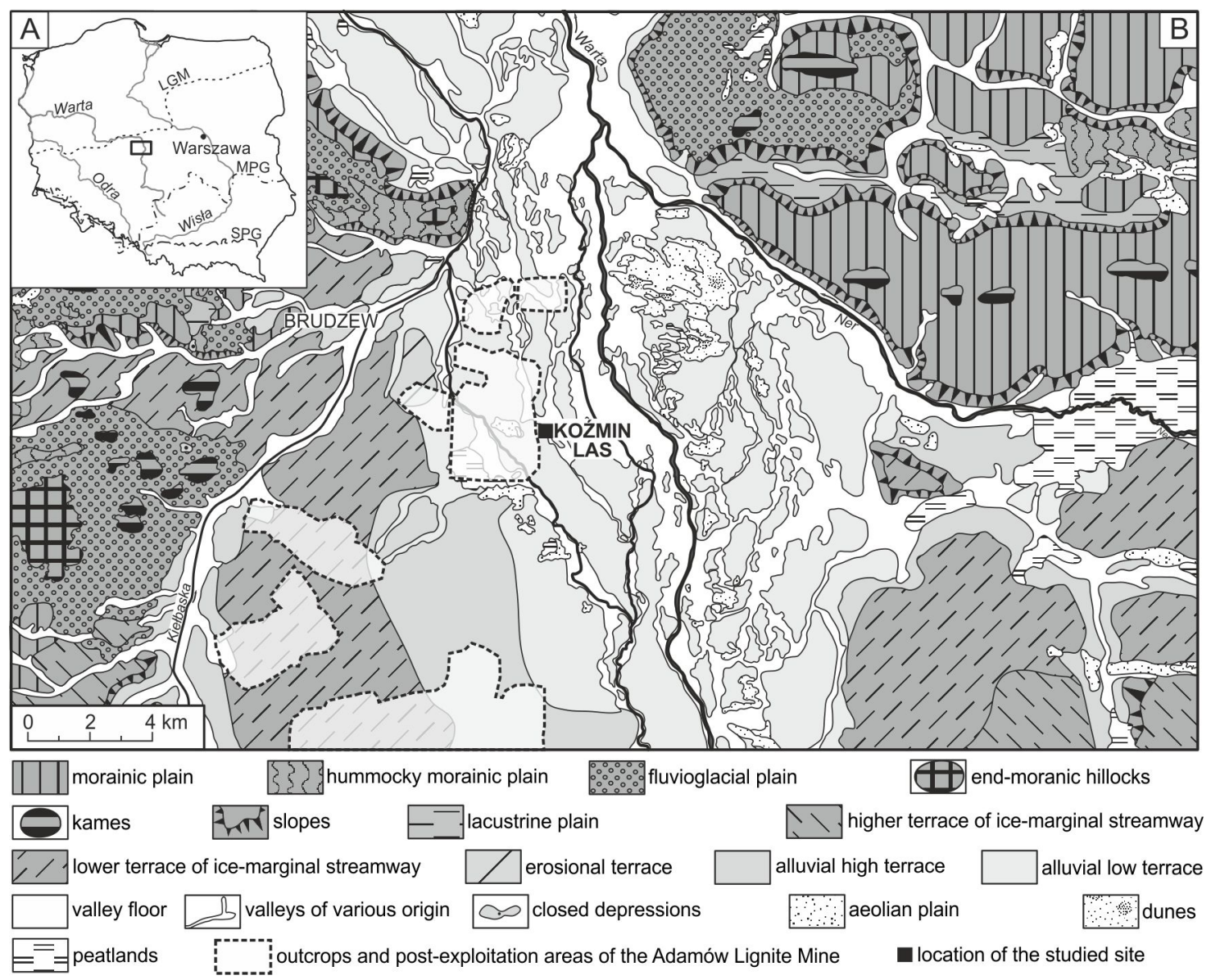

Fig. 1. Location of the Koźmin Las site against extents of the ice-sheets (after Marks, 2005); on the geomorphological map of the Warta valley and surroundings (after Forysiak, 2005). 
the palaeogeographical background of the overlying organic-rich series.

The middle unit, of a thickness up to $50 \mathrm{~cm}$, consists of peat and organic silt with an assemblage of tree remains, including stumps in situ. It is a well-dated profile whose age has been determined using the radiocarbon method (Dzieduszyńska et al., 2012; 2014). Radiocarbon conventional ages were determined using the scintillation technique in the Laboratory of Absolute Dating in Skała and in the Laboratory of the Museum of Archaeology and Etnography in Łódź (17 dates of tree trunks and 4 dates of organic silt) while the AMS technique was applied in the Poznan Radiocarbon Laboratory (5 dates of pine and birch remains). The conventional age determination was calibrated using the calibration data set IntCal09 (Reimer et al., 2009) and OxCal calibration program ver. 4.1.7 (Bronk Ramsey, 2001, 2009).

On the basis of obtained ages the formation of this part of the profile took place in the period not shorter than between 12 900-12 600 (95.4\%) cal BP (Poz-50356) and 11 600-10 770 (95.4\%) cal BP (MKL-1077). The data for the trees cover the period since 13 050-12 $640(95.4 \%)$ cal BP (MKL-1656) until 12 520-11 770 (95.4\%) cal BP (LOD-1402) (Dzieduszyńska et al., 2014).

The ${ }^{14} \mathrm{C}$ ages indicate that the unit was formed during the late Alleröd and the Younger Dryas period. The material from the middle unit was also a subject of a multiproxy paleoecological study, including dendrological approach and analysis of pollen, plant macrofossil, Cladocera and Chironomidae. It showed short terrestrial events interrupted by flood episodes. Among the terrestrial events was the existence of pine forest which grew in the floodplain of the Warta River for about 140-150 years and died in response to a climatic cooling at the beginning of the Younger Dryas and further deteriorating conditions (Dzieduszyńska et al., 2014). A record of palaeoenvironmental changes registered at the Koźmin Las site from the middle unit deposits is suited to the abrupt environmental changes of the last Late Glacial (Lowe et al., 2001, 2008; Broecker, 2006).

The upper unit is interpreted as river alluvium. It is composed of 2-3 m thick sandy and sandy silty deposits. The unit was classified as an overbank facies of an anabraching river type 2 (Turkowska et al., 2004).

\section{METHODOLOGY}

The nature of sedimentary environments and processes dynamics was inferred from analyses of structural and textural properties of the mineral sediments of the upper unit. Sedimentological analyses were carried out according to the Miall (1978) code modified by Zieliński and Pisarska-Jamroży (2012).

For the present study five samples from the upper mineral unit, one sample from the sandy lens within the organic unit and one sample from the topmost part of the lower unit were collected in order to date them using optically stimulated luminescence (OSL). The sampling was done manually from a cleaned vertical section and the samples were taken by inserting tubes into the profile. The sample form the sandy lens was taken as a monolith dissected from the profile (Fig. 2). The samples were taken from a depth range of 2.58 to $1.25 \mathrm{~m}$. The measurements were performed at the Gliwice Luminescence Laboratory (Silesian University of Technology).

All samples were dried in the laboratory. Highresolution gamma spectrometry using a HPGe detector manufactured by Canberra was carried out in order to determine the content of $\mathrm{U}, \mathrm{Th}$ and $\mathrm{K}$ in the samples. Before the measurement, the samples were stored for ca. 3 weeks to ensure equilibrium between gaseous ${ }^{222} \mathrm{Rn}$ and ${ }^{226} \mathrm{Ra}$ in the ${ }^{238} \mathrm{U}$ decay chain. Each measurement lasted for at least 24 hours. Annual doses were calculated using the conversion factors of Adamiec and Aitken (1998).

The cosmic ray dose-rate to the site was determined as described by Prescott and Hutton (1994). We assumed that the average water content was no higher than $15 \%$ and consequently used a value of $(18 \pm 4) \%$ for further calculations. Based on these data, the average dose rates were calculated (see Table 1).

For OSL measurements, coarse grains of quartz (90$125 \mu \mathrm{m})$ were extracted from the sediment samples by routine treatment with $20 \%$ hydrochloric acid $(\mathrm{HCl})$ and $20 \%$ hydrogen peroxide $\left(\mathrm{H}_{2} \mathrm{O}_{2}\right)$. The quartz grains were separated using density separation with the application of sodium polytungstate solutions leaving grains of densities between $2.62 \mathrm{~g} / \mathrm{cm}^{3}$ and $2.75 \mathrm{~g} / \mathrm{cm}^{3}$. The grains were sieved twice, before and after the 60 min etching with concentrated hydrofluoric acid (HF).

An automated Daybreak 2200 TL/OSL reader (Bortolot, 2000) was used for the OSL measurements of multi-grain aliquots. The aliquots were prepared by

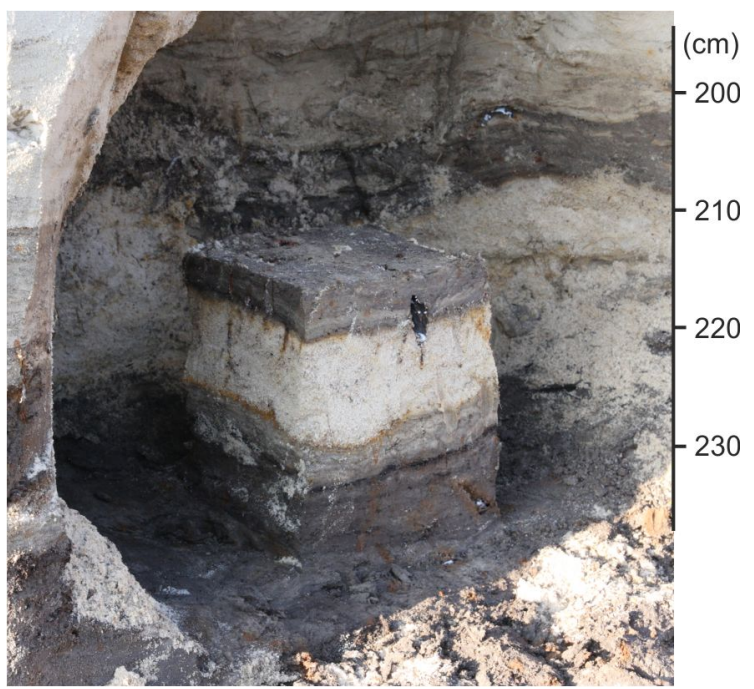

Fig. 2. Monolith prepared to collecting to OSL dating of the sandy lens within organic deposits (Photo J. Petera-Zganiacz). 
Table 1. Basic information about investigated samples with dose rates and ages calculated using CAM.

\begin{tabular}{ccccccc}
\hline Sample No & Depth $(\mathrm{cm})$ & Sample description & Dose rate $(\mathrm{Gy} / \mathrm{ka})$ & OSL age $(\mathrm{b} 2 \mathrm{k})$ & Laboratory No & Sampling method \\
\hline 1 & 125 & fine sand and silt & $1.111 \pm 0.043$ & $14310 \pm 660$ & GdTL-1515 & tube \\
\hline 2 & 135 & fine sand and silt & $1.344 \pm 0.049$ & $13690 \pm 680$ & GdTL-1516 & tube \\
\hline 3 & 140 & fine sand and silt & $1.258 \pm 0.044$ & $12780 \pm 620$ & GdTL-1410 & tube \\
\hline 4 & 170 & fine sand and silt & $0.938 \pm 0.034$ & $5750 \pm 350$ & GdTL-1411 & tube \\
\hline 5 & 175 & fine sand and silt & $0.938 \pm 0.037$ & $14330 \pm 740$ & GdTL-1517 & tube \\
\hline 6 & 224 & sand & $0.684 \pm 0.026$ & $13140 \pm 920$ & GdTL-1413 & monolith \\
\hline 7 & 258 & sand & $0.645 \pm 0.024$ & $13130 \pm 730$ & GdTL-1412 & tube \\
\hline
\end{tabular}

spraying silicone oil onto 10 -mm-diameter stainless steel discs through a mask with holes of a diameter of ca. $6 \mathrm{~mm}$ and attaching the grains to the oil-covered areas. For blue light stimulation an array of blue LEDs $(470 \pm 4 \mathrm{~nm})$ delivering about $60 \mathrm{~mW} / \mathrm{cm}^{2}$ at sample position was used. Laboratory irradiations were made using a calibrated ${ }^{90} \mathrm{Sr} /{ }^{90} \mathrm{Y}$ beta source integrated to the reader delivering a dose rate of $4.91 \mathrm{~Gy} / \mathrm{min}$.

For the samples, equivalent doses were determined using the single-aliquot regenerative-dose (SAR) protocol (Murray and Wintle, 2000). The OSL SAR protocol which was used in our measurements contained the following steps:

1) Irradiation with the regenerative beta dose $D_{\mathrm{i}}$

2) Preheat at the temperature $260^{\circ} \mathrm{C}$ for $10 \mathrm{~s}$

3) Blue light stimulation at the temperature $125^{\circ} \mathrm{C}$ for $100 \mathrm{~s}$

4) Irradiation with the test dose $D_{\mathrm{t}}(10 \%$ of the natural dose, but not less than $5 \mathrm{~Gy}$ )

5) Cut-heat at the temperature $220^{\circ} \mathrm{C}$

6) Blue light stimulation at the temperature $125^{\circ} \mathrm{C}$ for $100 \mathrm{~s}$.

The SAR dose response curves were best represented by a single saturating exponential. The obtained dating results for this site were calculated using the Central Age Model (CAM), Galbraith et al. (1999) and are presented in Table 1.

\section{RESULTS}

The topmost part of the lower unit consists of sand deposited in a sand-bed braided river environment. Properties of the deposit at the Koźmin Las site allowed to distinguish between channel an overbank subenvironments. Ripple and horizontal lamination of medium- and fine-grained sands ( $\mathrm{Sr}, \mathrm{Sh}$ ) constituting the topmost part of the series points to the deposition on a floodplain (Fig. 3).

In the middle unit the massive structure of silt and organic mud dominates $(\mathrm{C}, \mathrm{FCm}, \mathrm{Fm})$. In the upper part, appears sandy silty layer with horizontal lamination (SFh) (Fig. 3). The deformation of the internal structure of the series is caused by the presence of numerous tree remnants. Flat-bottomed structures, slight undulations and drop structures registered at the base of the unit result from a load casting (Anketell et al., 1970). The middle unit was deposited in a distal floodplain environment of a single channel or anabranching river system.

The upper unit is composed of sand and silt lithofacies. Four main sand lithofacies with ripple lamination (Sr) are separated by finer material: silty sand and sandy silt with horizontal or flaser laminated (SFh, FSh, SFf) (Fig. 3). The contact between one of the sand lithofacies and the underlying lithofacies is of erosional character which suggests a higher dynamics of fluvial processes during the deposition. Towards the top sand lithofacies are thinner, with low-angle cross-stratification (Sl) or massive structure $(\mathrm{Sm})$. The iron compounds indicate fluctuations of the former groundwater level. From $80 \mathrm{~cm}$ upwards the deposit is strongly transformed by soil processes while the topmost part of the profile is destroyed by coal mining activities (the investigated site is located very close to the recultivated outcrop). The deposition of the upper unit is attributed to a proximal floodplain of an anabranching river type 2 .

The upper unit is almost completely of the minerogenic origin. Only the lower part of the unit is relatively rich in organic matter, in the form of fine detritus dispersed in sandy silt, which comes from the washing out the underlying organic deposits. Besides, sandy lithofacies with ripple cross-stratification contain few small coal fragments. The characteristic feature of the base of the unit is the occurrence of tree trunks. The most probably these tree remnants were incorporated from the middle unit during floods.

The OSL analysis of the topmost part of the lower unit gave the result $13130 \pm 730 \mathrm{~b} 2 \mathrm{k}$. The resulting date of the sample taken from sandy lens within the organic unit was $13140 \pm 920 \mathrm{~b} 2 \mathrm{k}$. The results yielded for 4 samples of the upper fluvial unit, overlying the organic material, range from $12780 \pm 620 \mathrm{~b} 2 \mathrm{k}$ to $14330 \pm 740$ $\mathrm{b} 2 \mathrm{k}$, while the dating of the fifth sample indicated $5750 \pm 350 \mathrm{~b} 2 \mathrm{k}$. Location of the samples and OSL dating results are given in Figs. 3, 4 and Table 1.

\section{DISCUSSION}

The main scientific problem is the time of formation of sandy-silty material of the upper unit, which OSL age seems overestimated in relation to the timing of events leading to the formation of the organic-rich series, whose age is approximated with radiocarbon dates. Taking into 

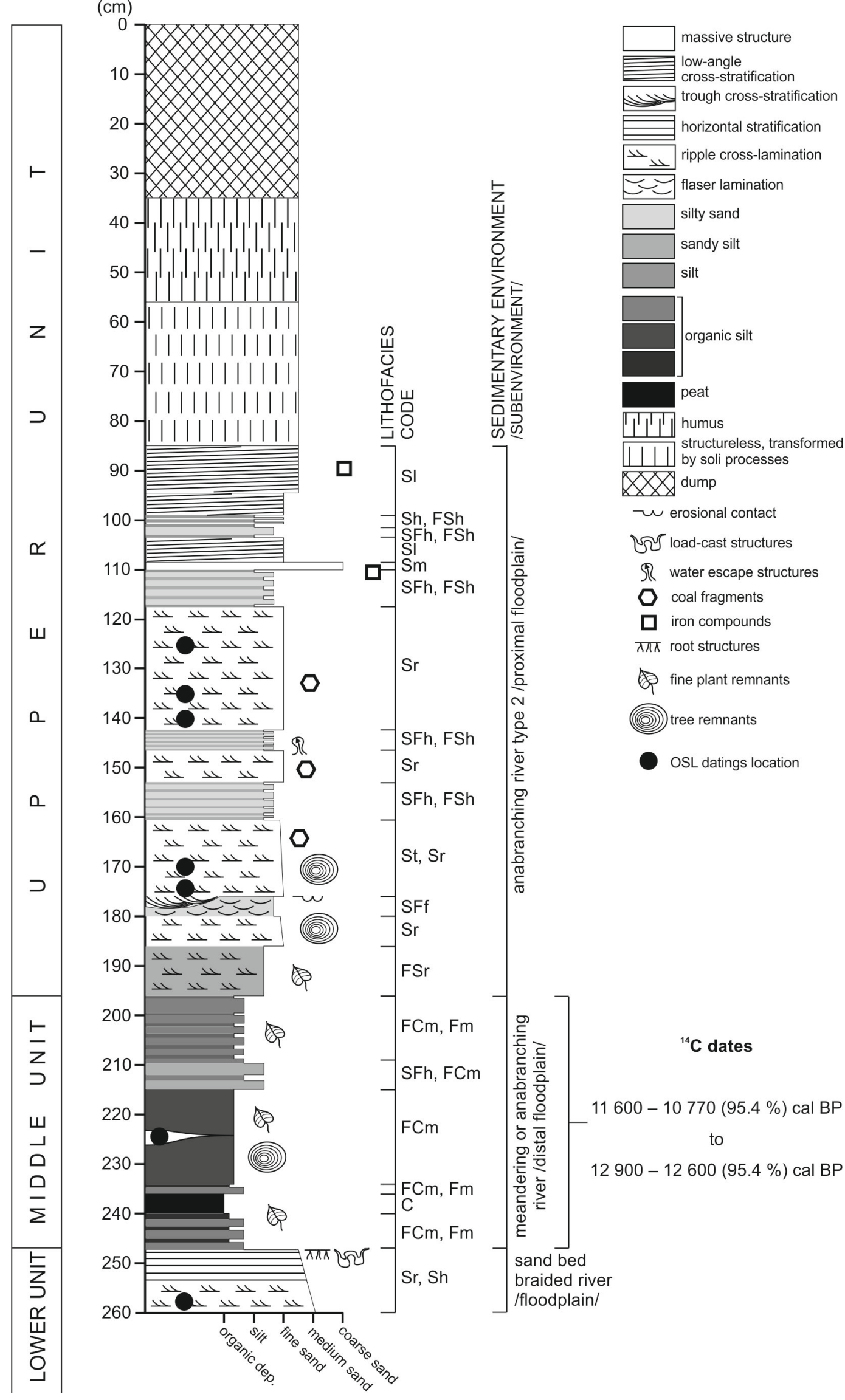


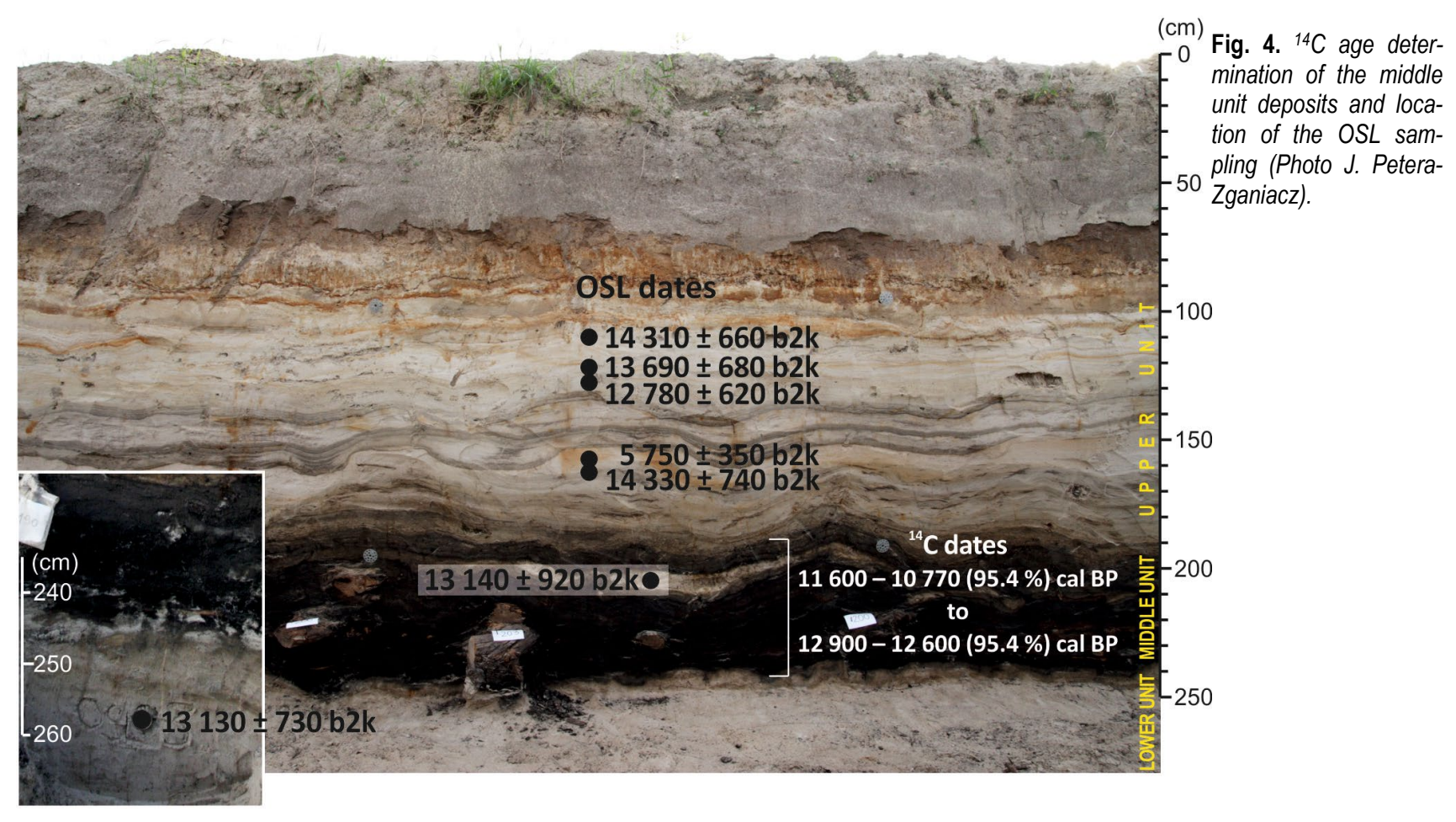

account the Walanus and Goslar (2009) opinion, it may be assumed that compared to $5 \%$ analytical error of OSL dates, the deposits both underlying and overlying the organic sequence are of the same age. As there is no reasonable explanation of such a situation with geologi$\mathrm{cal} /$ sedimentological circumstances, incomplete bleaching of the previously accumulated dose is likely the most probable cause.

The source material for the overbank upper series was derived from Late Weichselian alluvia. The sample from the topmost part of the lower unit gave an OSL date of $13130 \pm 730 \mathrm{~b} 2 \mathrm{k}$, thus the age of these fluvial deposits has been estimated to be younger than suggested in the earlier studies. A new dating result indicates that their formation may have lasted up to Weichselian late glacial beginnings. These deposits dominate in the fossil bottom of the valley throughout the study area. Only where the extensive (up to a few square kilometers), shallow (1$1.5 \mathrm{~m}$ ) basin occupied by swamps, initial peatbogs and riparian forest, was formed (Dzieduszyńska et al., 2012; Kittel et al., 2012), they became covered with organic material of the middle unit. Indistinct edges of the basin, to which the organic series comes up, were probably intensively eroded during the subsequent floods.

As the Hjulstrom diagram, modified by Sundborg (1956) shows, the fraction of fine- and medium-grained sands is most susceptible to set in motion in the fluvial environment; their erosion occurs already in the water at a depth of $1 \mathrm{~m}$ and current velocity below $0.5 \mathrm{~m} \cdot \mathrm{s}^{-1}$. A possibility of taking by flood waters a material different than that resting below the organic unit seems very lim- ited, mainly due to significant extension of the Warta River valley in the studied section. On the one hand, it is a factor contributing to determining the age of redeposited material. At the same time, there is also an unfavorable factor - the overbank deposits of an anabranching river type 2 were accumulated under conditions in which achieving the zero value of the luminescence level was difficult. Transport of these deposits took place in the near-bottom waters by traction, saltation and intermittent suspension (Gradziński et al., 1986). Waters which periodically flooded the basin with remnants of tree trunks were loaded with suspension which caused cutting off from light to the bottom, while the transport intensity as well as the sedimentation ratio were probably significant.

Because OSL samples within the upper unit were taken from the layers with ripple cross-lamination containing coarser grains and of largest thickness ( $\mathrm{Sr}$ ), these deposits might have been not exposed to light at all after falling of a flood wave. It can be assumed that more reliable OSL ages could be obtained from the thin layers of silty sands and silts (SFh, FSh) alternating the dated sands. Lithofacies SFh, FSh represent a waning stage of river flood and were deposited due to slackening water current or even no movement of grains and a considerably shallower flow (Zieliński, 1995, 1998). The topmost portions of horizontally stratified silts in postflood conditions could at least temporarily make the topographic surface of the floodplain and be exposed to light. Nevertheless, as the OSL sampling procedure requires collecting a large volume of deposit to a tube with a diameter which in the studied 
profile exceeded the thickness of the layer, it was impossible to use the silts for the age determination.

As mentioned earlier, radiocarbon dating from the organic material places the middle unit in the time of extreme and rapid environmental changes of the very end of the Weichselian. The chronostratigraphical division of the Last Termination based on data from both continental deposits (e.g. Mangerud et al., 1974; Litt et al., 2001; Starkel et al., 2013) and Greenland ice cores (Björck et al., 2008) points to the short stratigraphic phases defining palaeogeographical events. Also the duration of the individual events in the study area, including the forest existence and deposition of the whole organic series, was relatively short. An attempt to establish timing of events in the valley, taking place before and after the wellrecognized episode of the forest existence, has been not fully successful. It should be emphasized that a few percent error limits of the OSL dates, ranging from \pm 620 to \pm 740 years, exceed the forest duration or possibly a period of the formation of the whole organic-rich unit. Therefore, in the presented case, the limitations of the OSL method to precise dating of short events, in terms of a geological time scale, and to dating of deposits attributed to a quick sedimentation are superimposed.

\section{ACKNOWLEDGEMENTS}

The research is financially supported by a grant from the National Science Centre, No N N306 788240 "Palaeogeographical conditions of existence and destruction of the Late Weichselian forest in the Warta River Valley (the Koło Basin)". The authors wish to thank the Reviewers for their suggestions and comments. We like to thank the local government of the Brudzew Commune Office for their help and support during our fieldwork.

\section{REFERENCES}

Adamiec G and Aitken MJ, 1998. Dose-rate conversion factors: update. Ancient TL 16: 37-50.

Anketell JM, Cegła J and Dżułyński S, 1970. On the deformational structures in systems with reversed density gradients. Rocznik Polskiego Towarzystwa Geologicznego 40(1): 3-29.

Björck S, Walker M, Cwynar L, Johnsen S, Knudsen K.-L, Lowe J, Wohlfarth B and INTIMATE Members, 1998. An event stratigraphy for the last Termination in the North Atlantic region based on the Greenland ice-core record: a proposal by the INTIMATE group. Journal of Quaternary Science 13(4): 283-292, DOI 10.1002/(SICI)1099-1417(199807/08)13:4<283::AIDJQS386>3.0.CO;2-A.

Bortolot VJ, 2000. A new modular high capacity OSL reader system. Radiation Measurements 32(5-6): 751-757, DOI 10.1016/S13504487(00)00038-X.

Broecker WS, 2006. Abrupt climate changes revisited. Global and Planetary Change 54(3-4): 211-215, DOI 10.1016/j.gloplacha.2006.06.019.

Bronk Ramsey C, 2001. Development of the radiocarbon calibration program. Radiocarbon 43(2A): 355-363.

Bronk Ramsey C, 2009. Bayesian analysis of radiocarbon dates. Radiocarbon 51: 337-360.

Czubla P, Forysiak J, Petera-Zganiacz J, Grajoszek M and Wiśniewska M, 2013. Charakterystyka litologiczno-pertograficzna osadów czwartorzędowych w dolinie Warty (stanowisko Koźmin-Północ) (The lithological and petrographic features of the Quaternary deposits in the Warta River valley (Koźmin-North site). Przeglad Geologiczny 61(2): 120-126 (in Polish with English summary).

Dzieduszyńska D and Petera-Zganiacz J, 2012. Geologic position of the Younger Dryas subfossil forest in the Warta River Valley, central Poland. Bulletin of the Geological Society of Finland 84: 69-79.

Dzieduszyńska D, Kittel P, Petera-Zganiacz J, and Twardy J, 2012. Paleogeograficzne elementy rozwoju doliny Warty w Kotlinie Kolskiej w świetle badań w stanowisku „Koźmin Las” (Palaeogeographical elements of the Warta River evolution within the Koło Basin in the light of investigations at the site "Koźmin Las"). Acta Geographica Lodziensia 100: 35-50 (in Polish with English summary).

Dzieduszyńska D, Kittel P, Petera-Zganiacz J, Brooks SJ, Korzeń K, Krapiec M, Pawłowski D, Płaza DK, Płóciennik M, StachowiczRybka R and Twardy J, 2014. Environmental influence on forest development and decline in the Warta River Valley (Central Poland) during the Late Weichselian. Quaternary International 324: 99-114, DOI 10.1016/j.quaint.2013.07.017.

Forysiak J, 2005. Rozwój doliny Warty między Burzeninem a Dobrowem po zlodowaceniu warty (The development of the Warta River Valley between Burzenin and Dobrów in the late Quaternary period). Acta Geographica Lodziensia 90: 116 pp (in Polish with English summary).

Galbraith RF, Roberts RG, Laslett GM, Yoshida H and Olley JM, 1999. Optical dating of single and multiple grains of quartz from Jinminum Rock Shelter, Northern 12 Australia. Part I, experimental design and statistical models. Archaeometry 41(2): 339-364, DOI 10.1111/j.1475-4754.1999.tb00987.x.

Gradziński R, Kostecka A, Radomski A and Unrug R, 1986. Zarys sedymentologii (Sedimentology). Wyd. Geolog., Warszawa: 628 pp (in Polish).

Kittel P, Petera-Zganiacz J, Dzieduszyńska D, Twardy J, Krapiec M, Bijak Sz, Bronisz K, Zasada M and Płaza D, 2012. Badania „kopalnego lasu" ze schyłku vistulianu w dolinie Warty, Kotlina Kolska, środkowa Polska (Research of subfossil forest from the Weichselian decline in the Warta River Valley, Koło Basin, central Poland). Studia $i$ Materiaty Centrum Edukacji PrzyrodniczoLeśnej 1(30): 238-245 (in Polish with English summary).

Litt T, Brauer A, Goslar T, Merkt J, Bałaga K, Müller H, RalskaJasiewiczowa M, Stebich M and Negendank JFM, 2001. Correlation and synchronisation of Lateglacial continental sequences in northern central Europe based on annually laminated lacustrine sediments. Quaternary Science Reviews 20(11): 1233-1249, DOI 10.1016/S0277-3791(00)00149-9.

Lowe JJ, Hoek WZ and INTIMATE group, 2001. Inter-regional correlation of palaeoclimatic records for the Last Glacial-Interglacial Transition: a protocol for improved precision recommended by the INTIMATE project group. Quaternary Science Reviews 20(11): 1175-1187, DOI 10.1016/S0277-3791(00)00183-9.

Lowe JJ, Rasmussen SO, Björck S, Hoek WZ Steffensen JP, Walker MJC, Yu ZC and the INTIMATE group, 2008. Synchronization of paleaoenvironmental events in the North Atlantic region during the Last Termination: a revised protocol recommended by the INTIMATE group. Quaternary Science Reviews 27(1-2): 6-17, DOI 10.1016/j.quascirev.2007.09.016.

Mangerud J, Anderson ST, Berglund BE and Danner JJ, 1974. Quaternary stratigraphy of Norden, a proposal for terminology and classification. Boreas 3(3): 109-126, DOI 10.1111/j.15023885.1974.tb00669.x.

Marks L, 2005. Pleistocene glacial limits in the territory of Poland. Przeglad Geologiczny 53: 988-993.

Miall AD (ed.), 1978. Fluvial Sedimentology. Canadian Society of Petrolium Geologists Memoir 5: 859 pp.

Murray AS and Wintle AG, 2000. Luminescence dating of quartz using an improved singlealiquot regenerative-dose protocol. Radiation Measurements 32(1): 57-73, DOI 10.1016/S1350-4487(99)00253$\mathrm{X}$

Petera J, 2002. Vistuliańskie osady dolinne w basenie uniejowskim i ich wymowa paleogeograficzna (Vistulian valley deposits in the 
Uniejów Basin and their palaeogeographical significance). Acta Geographica Lodziensia 83: 174 pp (in Polish with English summary).

Prescott JR and Hutton JT, 1994. Cosmic ray contributions to dose rates for luminescence and ESR dating: large depths and long-term time variations. Radiation Measurements 23(2-3): 497-500, DOI 10.1016/1350-4487(94)90086-8.

Reimer PJ, Baillie MGL, Bard E, Bayliss A, Blackwell PG, Bronk Ramsey C, Buck CE, Burr GS, Edwards RL, Freidrich M, Grootes PM, Guilderson TP, Hajdas I, Heaton TJ, Hogg AG, Hughen KA, Kaiser KF, Kromer B, McCormac G, Manning S, Reimer RW, Richards DA, Southon JR, Talamo S, Turney CMS, van der Plicht $\mathrm{J}$ and Weyhenmeyer CE, 2009. Intcal09 and Marine09 radiocarbon age calibration curves, 0-50 000 years cal BP. Radiocarbon 51: $1111-1150$.

Starkel L, Michczyńska DJ, Krąpiec M, Margielewski W, Nalepka D and Pazdur A, 2013. Progress in the Holocene chronoclimatostratigraphy of Polish territory. Geochronometria 40(1): 121, DOI 10.2478/s13386-012-0024-2.

Sundborg A, 1956. The River Klarälven: a study of fluvial processes. Geografiska Annaler 38: 125-237, DOI 10.2307/520140.

Turkowska K, Forysiak J, Petera J and Miotk-Szpiganowicz G, 2004. A Warta River system during the Younger Dryas in the Koło Basin (Middle Poland). Quaestiones Geographicae 23: 83-107.
Walanus A and Goslar T, 2009. Datowanie radiowęglowe (Radiocarbon dating). Wyd. AGH, Kraków: 147 pp (in Polish).

Widera M, 2007. Litostratygrafia i paleotektonika kenozoiku podplejstoceńskiego Wielkopolski (Lithostratigraphy and palaeotectonics of the sub-Pleistocene Cenozoic of Wielkopolska). Wyd. Naukowe UAM, Seria Geologia 18: 223 pp (in Polish with English summary).

Zieliński T, 1995. Kod litofacjalny i litogenetyczny - konstrukcja i zastosowanie (Lithofacies and genetic codes: construction and application). In: Mycielska-Dowgiałło E and Rutkowski J, Eds., Badania osadów czwartorzędowych. Wybrane metody i interpretacja wyników. WGiSR UW, Warszawa: 220-235 (in Polish with English summary).

Zieliński T, 1998. Litofacjalna identyfikacja osadów rzecznych (Lithofacial identification of alluvial sediments). In: MycielskaDowgiałło E, Ed., Struktury sedymentacyjne i postsedymentacyjne w osadach czwartorzędowych i ich wartość interpretacyjna. WGiSR UW, Warszawa: 193-257 (in Polish with English summary).

Zieliński T and Pisarska-Jamroży M, 2012. Jakie cechy litologiczne osadów warto kodować, a jakie nie? (Which features of deposits should be included in a code and which not?). Przeglad Geologiczny 60(7): 387-397 (in Polish with English summary). 